\title{
Reconciliation as Ideology and Politics
}

Andrew Schaap

This is a pre-print of an article that is forthcoming in Constellations: An International Journal of Democratic and Critical Theory, 2008.

ABSTRACT: Against the critique of reconciliation as an irredeemably ideological concept, I want to retrieve the concept of reconciliation for a popular politics. As a term of political discourse, reconciliation bas been objected to for being: too vague, illiberal, question-begging, assimilative, quietist and exculpatory. Each objection draws attention to the tendency of every state-sanctioned project of reconciliation to become ideological in the Marxist sense. In contrast, a politics of reconciliation would: be enabled by the contestability of what 'real' reconciliation requires; refer to buman rights in their constitutive political sense; invoke moral community to politicise the terms of political belonging; acknowledge the risk that the beginning it seeks to enact in the present may not come to pass; be predicated on a gratitude that a willingness to forgive makes reconciliation available as political opportunity in the first place, and; conceive collective responsibility in terms of an ongoing responsiveness to the legacy of past wrongs that might unite the community-to-be-reconciled.

Since Marx's critique of Hegel, reconciliation has often been suspected of being an inherently conservative concept because it casts social conflict as always in the service of the unity of the state. ${ }^{1}$ As such, it dissimulates the fundamental contradictions at stake in class conflict, the consciousness of which would radically call into question the terms of political association. ${ }^{2}$ Starting from an acknowledgement of this historical scepticism toward the concept of reconciliation within radical theory, in this article I outline six objections to the framing of politics in terms of reconciliation that emerged in popular and academic debates about reconciliation in Australia and elsewhere in the 1990s. Among other things, the concept of reconciliation stands accused of being: too vague to form a coherent political project; illiberal because it looks forward to an ideal of community that is not compatible with the pluralism of modern societies; question-begging since it aims to restore a prior state of harmony that never actually existed; assimilative in that it represents the political claims of the ruled only in terms 
commensurate with the interests of the rulers; quietist insofar as it demands resignation to the injustices of the past and forgoing resentment of their continuing legacy; and exculpatory in that it provides an opportunity to redeem the good conscience of the nation primarily through symbolic gestures.

Each of these objections underwrites the legitimate concern that reconciliation might become ideological because it invokes the common good to legitimate a particular order in which the interests of some are privileged over those of others. Consequently, there may good strategic reasons for a party to a conflict to refuse to couch its political claims in terms of reconciliation. ${ }^{3}$ However, to concede the ideological capture of reconciliation entirely to its conservative appropriators might also be a strategic error. In this article, I therefore seek to rehabilitate the concept of reconciliation for an emancipatory politics by refuting several principled objections that are often raised by critics of reconciliation processes. By outlining and responding to these six negative claims against reconciliation as ideology, I aim to construct a positive account of reconciliation as politics. In doing so, I want to resist the conclusion that reconciliation, which might currently be considered a 'ruling idea' within the international community, is necessarily 'an idea of the ruling class. ${ }^{4}$

As such, this article is inspired by what Costas Douzinas describes as a Gramscian form of critique, according to which:

...political ideas and concepts are neither true nor false but the tools through which we make sense of our world. In law and politics, therefore, the task is not so much to discard wrong ideological concepts but to re-define them against whatever conservative connotations they may have acquired, adjust them to the project of popular politics and build around them a 'hegemonic' bloc. ${ }^{5}$

This is not to say that each of the objections outlined below are articulated in terms of the orthodox Marxist critique of ideology. Far from it. However, taken together, these objections draw attention to a common division among observers and practitioners of reconciliation processes: on the one side we are often presented with an anodyne view of reconciliation as promising to redeem the fallen realm of politics; on the other side, there is a tendency toward totalising critique that views reconciliation as invariably masking the realities of power politics. 
Against falling prey to either reduction, I agree with Stewart Motha that it is necessary to grapple with the 'double move' of reconciliation as both 'emancipatory demand [politics] and device by which an enforced commonality can be reinscribed [ideology]. ${ }^{6}$ Analysing reconciliation as ideology and politics thus leads to the heart of the problem of the political (the thematisation of commonality) and the staging of politics (the representation of conflict). While the politics of transitional justice bring the problem of the political to the fore, this problem also takes us beyond the particular dilemmas confronting 'transitional societies'. Indeed, the problem of the political is arguably the fundamental concern of all political theory, understood in its broadest sense as inquiry into the origin of law and the end of political community.

\section{The Ambiguity Objection}

Reconciliation, it is often complained, means too many different things to too many different people for it to be a coherent ideal towards which members of a divided society might strive. For instance, Andrew Gunstone notes that during the formal reconciliation process in Australia there were 'a multitude of differing definitions of reconciliation advocated by various individuals and organizations, that emphasised issues as diverse as Indigenous rights, religion, assimilation, acknowledging history and the need for Indigenous and non-Indigenous people to accept their current situation.' Gunstone identifies the consequent 'confusion within the wider Australian community over the meaning of reconciliation' as one of the factors that contributed to its failure as a public policy. ${ }^{7}$

To counter this objection, we need to distinguish the concept of reconciliation, from its various conceptions. The concept of reconciliation might be defined in a non-controversial way, as for instance, a public reckoning with a history of political violence and oppression and their legacy in order to enable people divided by that past to coexist within one political community and to recognise the legitimacy of its law. ${ }^{8}$ As with other political ideals, it is hard for political actors to oppose reconciliation when understood in these terms. Consequently, the politics of reconciliation becomes apparent in the competing conceptions of reconciliation that emerge in 
public debates about how it might be achieved, what 'real' or 'true' reconciliation would require. In other words, reconciliation is, like every other political concept, 'effectively contestable."

At least three conceptions of reconciliation emerged, for instance, in public debates in Australia in the 1990s. The self-proclaimed 'practical' conception of reconciliation favoured by the Howard government was ostensibly premised on a universalist ideal of distributive justice and focused on achieving equity between indigenous and non-indigenous citizens in terms of socioeconomic indicators of well-being such as health, education, housing and employment. ${ }^{10}$ The restorative conception favoured by the Opposition (and derisively labelled 'symbolic' by the Government) was based on reparative justice and emphasised the collective responsibility of non-indigenous Australians for past injustices. Among other things, it required an official apology and reparations to the stolen generations and their families. ${ }^{11}$ In mainstream debates about the merits of practical versus restorative reconciliation, the constitutional conception of reconciliation favoured by most indigenous leaders often went unacknowledged. It appealed to the democratic ideal of self-determination and emphasised the importance of a treaty, indigenous rights, Aboriginal sovereignty and constitutional recognition. ${ }^{12}$

In such circumstances, it is not clear that greater definitional precision over the meaning of reconciliation would make its achievement more likely. Rather, it might polarise a population further by raising the stakes of the conflict in terms of whether to reconcile or not. In contrast, as Michael Freeden puts it, 'ambiguity...is a recipe for political coexistence' since it enables support to be mobilised for a shared enterprise among plural constituencies. ${ }^{13}$ Moreover, since its allows reconciliation to be a contestable project from the outset, the ambiguity of the concept can be understood as an enabling condition for politics among people in a divided society. If we had to agree on a definition of reconciliation before we could begin to reconcile, reconciliation would never be initiated. Yet a willingness to reconcile, enabled by the ambiguity contained within such a collective intention, might provide the basis for an overlapping dissensus in relation to which people can debate and contest the terms of their political association. An overlapping consensus refers to a (public) agreement on the fundamental principles of legitimacy in a well-ordered society, which may be supported from a plurality of potentially competing (private) conceptions 
the good (Rawls' liberalism). In contrast, an overlapping dissensus would refer to the bringing into view of the fundamental wrong that would unite the parties to reconciliation as members of the same political unity in the first place, which would be disclosed through an agonistic politics (Rancière's democracy). In this way, the contestability of the concept of reconciliation enables an agonistic politics that is potentially constitutive of political community: in contesting the significance of the social world according to the conflicting perspectives brought to bear on it, that world might become more common to those engaged in struggle. When brought to bear on political relations between indigenous and settler societies in Australia, for instance, the distributive, reparative and constitutional conceptions of reconciliation might intersect to reveal what is at stake in overcoming the legacy of colonisation in this country. When brought to bear on political relations between indigenous and settler societies in Australia, for instance, the distributive, reparative and constitutional conceptions of reconciliation might intersect to reveal what is at stake in overcoming the legacy of colonisation in this country.

In contrast, reconciliation becomes ideological when its meaning is over-determined. For it then tends to function as a meta-political ideal that disciplines conflict: it interpellates subjects in a way that renders their disagreement resolvable in terms commensurate with the new regime. ${ }^{14}$ Drawing on the work of Althusser, for instance, Claire Moon describes how, in the work of the TRC, reconciliation functions as 'an organising category that...imposes concordance in place of contestation, conditioning the way in which South Africa's history is related in symbolic and material ways': as a history of human rights violations rather than one of 'oppression, exploitation, cruelty, just war, or revolution'. ${ }^{15}$ Similarly, in Australia, reconciliation was ideological to the extent that indigenous peoples' claim to self-determination could not be articulated in terms of prevailing dispute within the settler society, which took for granted the cocitizenship of indigenous and non-indigenous people. ${ }^{16}$ If reconciliation depends on a population within a state coming to think of itself as a people, then a particular conception of reconciliation cannot be imposed in advance but must be worked out politically by those who would get together to reconcile in the first place. 


\section{The Illiberal Objection}

Reconciliation, it is sometimes said, presupposes an ideal of community that is too demanding for any modern society, let alone one deeply divided by a history of political violence. While reconciliation might be an appropriate term within the theological discourse in which it originated it makes no sense to talk of reconciliation in political life, in which the most we can aspire to is the containment of conflicts not their resolution. ${ }^{17}$ Hence Timothy Garton-Ash suggests that 'taken to the extreme the reconciliation of all with all is a deeply illiberal idea' since 'liberalism means living with unresolvable conflicts of values and goals. ${ }^{18}$ Reconciliation is ideological, on this account, when it imposes a comprehensive vision of community, which we could not reasonably expect all parties to a conflict to accept. Instead of seeking an unattainable social harmony we should pursue more limited goals such as peaceful coexistence and mutual toleration. $^{19}$

Underlying this objection is what Judith Shklar calls the 'liberalism of fear', which is predicated not any substantive idea of the common good but, rather begins from a recognition of 'a summum malum, which all of us know and would avoid if only we could. That evil is cruelty and the fear it inspires, and the very fear of fear itself. ${ }^{20}$ Liberalism, on this view, is premised on the negative promise 'Never Again' that is central to reconciliation processes. A thin liberal conception of reconciliation would be limited to a strong defence of equal rights and their legal protection, the affirmation of the rule of law, including the establishment of a culture of respect for human rights. The importance of reconciliation would be in commemorating the past as a history of violations of human rights in order to prevent their reoccurrence. ${ }^{21}$

I have already described the ideological aspect of reconciliation that liberalism identifies in terms of over-determination to which I proposed contestability as a remedy. In this section, I will deal instead with the ideological aspect of the 'thin' liberal conception of reconciliation. While purporting to be grounded in politics, this conception disavows the problem of the political. Shklar gives us a clue to this ideological aspect of reconciliation, when she describes the marriage of liberalism to democracy as one of convenience: democracy is only of instrumental worth to this variant of liberalism because it is the regime least likely to violate human rights. 
Reconciliation becomes ideological, when conceived in these terms, to the extent that it affirms human rights while only genuflecting to the ideal of popular sovereignty.

While rejecting the idea that the alienability of human rights is self-evident, the liberalism of fear insists that the recognition of political violence as Evil is self-evident and it is with this that we must take issue. For, as Alain Badiou observes, if the promise 'Never Again' is construed in terms of an 'ethical consensus founded on the recognition of Evil, it follows that every effort to unite the people around a positive idea of the Good...becomes in fact the real source of Evil itself. ${ }^{22}$ As such, reconciliation would disavow its own politics in the name of an 'ethics', which posits human rights as the higher moral principles according to which politics should be ordered.

Consequently it fails to grapple with the problem of the political. Namely, why those who happen to live in proximity to each other should look to the same law and political institutions to secure their basic rights. ${ }^{23}$ While it might be true that every person has an interest in securing certain basic rights for herself, each person also needs a reason why she should cooperate with others in a particular historical community to secure her rights in common. Conceived in terms of juridical conception of human rights, reconciliation takes for granted the 'fact' of an association of rights-bearing individuals because its interest in community is primarily instrumental: as a predictable environment in which legal persons can pursue their private freedoms.

Following a history of oppression in which the rights of some are denied in the name of political community, reconciliation minimally requires the legal recognition of all citizens of a new regime as entitled to equal rights. However, a politics of reconciliation must further address and articulate the substance of these rights and how they might come to be 'held' in common by members of a divided society; it cannot take their interest in securing them collectively to be 'selfevident'. As Rancière puts it, 'the simple relationship between humanity and its denial never creates a community of political dispute. ${ }^{24}$ Rather than simply appeal to the shared humanity of those divided by the past as the basis of political community, what is required is a demonstration of the wrong that would unite them in the context of a particular historical community. 
Writing in the context of Chile, Fernando Atria describes the way in which reconciliation as politics and ideology articulate by distinguishing between the legal conception of human rights ('grounding actionable claims against others') and their political aspect ('constitutive of the political community'). ${ }^{25}$ The problem with the legal conception of human rights is that it refers to the way in which human rights are instituted during normal times, whereas 'human rights violations' are always perpetrated during times of exception in which the law is suspended. ${ }^{26}$ Consequently, Atria argues, the promise 'Never Again' cannot be redeemed by normal legal means because it is unable to take account of the political context in which violence was perpetrated, the "social drama' of inhuman treatment of fellow human beings in exceptional situations, when the legal is suspended. ${ }^{27}$ A juridical conception of rights deals with the past by depoliticising the conflict as one among individual agents. In doings so, it fails to take account of what makes human rights violations so atrocious, namely, that they were collectively organised by the state and justified in the name of a people.

To the extent that a thin conception of reconciliation takes for granted individuals' private interests in securing human rights as already publicly shared it fails to address 'terror as something that affects the self-understanding of the political community that suffers it, so that

[for example] coming to terms with it is restoring the basis for the 'we' of 'we the Chileans. ${ }^{28}$ In other words, it fails to address the constitutive, foundational dimension of human rights that is implicit in the promise 'Never Again' insofar as it expresses a collective intention, an act of selfdetermination.

\section{The Question-Begging Objection}

Reconciliation, it is sometimes pointed out, refers to the 'restoration' of friendly relations after an estrangement. But in contexts of transitional justice there is often, in fact, no prior state of harmony that could be restored. In her analysis of the narrative framing of reconciliation by the TRC in South Africa, for instance, Claire Moon observes that:

Tutu's words call upon the prelapsarian human condition - the moment of creation - and hail a return to a condition of harmony and unity that preceded 
'The Fall'...Reconciliation... [suggests] that a condition of national harmony and accord in South Africa actually did exist prior to its alleged 'rupture'. All this...in the context of South Africa's 'stark circumstances' in which there is 'nothing to go back to, no previous state or relationship one would wish to restore'. ${ }^{29}$

In moral philosophy, the prior state of harmony refers to the moral community from which a wrongdoer becomes alienated in violating a communal norm and to which she or he is restored through a process of remorse, reparation and reaffirmation of the norm, followed by punishment and/or forgiveness. ${ }^{30}$ The problem with applying this account of reconciliation to divided societies is, of course, that we cannot presuppose shared norms between the persecutors (including their beneficiaries) and the persecuted. In a context such as Australia, in which violence and oppression against the colonised was legitimated in terms of the shared moral norms of the colonisers, indigenous people might quite rightly be suspicious of the 're' in reconciliation.

As with the liberal notion of 'restoring' the rule of law in a divided society, the presupposition of an original commonality to be restored begs the question since it presupposes as given what is actually a contingent achievement of politics. Yet there is a crucial difference between the 'thin' community presupposed by liberalism and the original harmony conceptually linked to the 're' in reconciliation: whereas liberalism takes for granted a determinate political community, the concept of reconciliation refers to an ideal moral community that is prior to (and so transcends) any actually existing political community. As such, the restorative aspect of reconciliation brings into relief the paradox of representing 'the people' in any democracy. For the "we" that is invoked to legitimate or challenge existing institutions never actually exists prior to those institutions but is always the achievement of political action. The people whose will the laws of a democratic society are supposed to express cannot actually speak as a people but can only ever be represented by specific actors and institutions. ${ }^{31}$ This is what Claude Lefort means when he claims that, in a democracy, the place of power is empty: the people is a quasitranscendent subject of democratic discourse that, contra Schmitt, is irreducible to any particular determination. ${ }^{32}$ 
For society to represent itself as a unity it must refer to a point outside its 'self' from which it can perceive itself as a whole. The 're' in reconciliation enables precisely this insofar as it refers to a counter-factual community (a utopia or ideal sociality prior to institutions) in terms of which members of a determinate political community might represent their society as a whole and imagine how it might otherwise be. Such reference to a counter-factual community is commonplace in political theory. For instance, it figures both in the 'state of nature' in social contract theory and the 'pragmatic presuppositions of communication' in Habermas's discourse ethics. But it originally derives from the religious imagination: the ideal of an original harmony (a form of non-alienated solidary co-existence among humans and between the human and the divine) provides a point of critique in terms of which we might understand how our actually existing society is and might otherwise be.

Reconciliation becomes ideological to the extent that the harmony that is to be 'restored' is reified and inscribed as an enforced commonality. Stewart Motha makes this point in his analysis of the (unratified) Declaration Towards Reconciliation in Australia. Citing the opening sentence 'We, the peoples of Australia, of many origins as we are, make a commitment to go on together in a spirit of reconciliation' - Motha argues that the Declaration is 'premised on a presumed and insistent 'commonality." ${ }^{33}$ Despite the recognition of plurality in its reference to 'peoples of many origins', he points out that this is held together by a singular 'We' that is premised on a concept of sovereignty in its 'original imperial terms: 'We recognise that this land and its water were settled as colonies without treaty or consent. ${ }^{34}$ There is here an explicit acknowledgement of the question-begging objection, an admission of the facticity of the political community with its origin in violence the fiction of any reference to an original harmony that might be restored. Yet, Motha argues, despite this confession there is also a 'preservation of the sovereign assertion that is at once finite (an event that took place 'back then') and infinite ('it can never be parted from or addressed').

As critique of the reconciliation process in Australia, Motha's analysis is acute. Yet, it tends toward totalising critique in its insistence that the sovereign assertion can never be addressed. I agree that this sovereign assertion cannot be legally redressed. ${ }^{35}$ Politically, however, the 're' in 
reconciliation is only potentially and not necessarily ideological and it can also serve to politicise and resist ideology by allowing us to imagine how the relation between indigenous and settler societies might be different, how the identities of coloniser and colonised might be resisted. ${ }^{36}$ Importantly, the singular 'We' that opens the Declaration is an indexical term: it can only point to a collectivity that remains indeterminate. Because the 'we' cannot speak as a 'we', someone must claim to represent it and it is this representative claim that may be contested and in for this reason it is not necessarily reducible that of the determinate political community. Politically, the significance of the Schmittian conception of the political on which Motha's analysis partly relies, is that it recognises the contingency of the substantive form of political unity that underlies every legal order, which means that it could always be otherwise.

A politics of reconciliation therefore requires distinguishing carefully between the unlimited moral community to which the 're' in reconciliation refers and the bounded political community that it calls into question. As such, reconciliation should not be understood as the end of politics. As Valerie Kerruish argues, the unity to which the 're' in reconciliation refers should not be sought in terms of an ideal community that a determinate community might be made to approximate: unity should not function as a regulative ideal. Rather, it should be understood in negative terms as 'not in this world' and in this sense related to it. As such, the unity to which the 're' in reconciliation refers does not provide a blue print for a new society as utopias are sometimes interpreted to do. Rather, 'its conceptual link is to freedom, in [the Australian] context, decolonisation., ${ }^{37}$

\section{The Assimilative Objection}

Perhaps the most common objection to the concept of reconciliation is that it privileges national unity and political stability over the requirements of justice. Reconciliation perpetuates assimilation to the extent that is takes for granted one nation that needs to be healed rather than recognising two (or more) distinct political communities. Stewart Motha describes reconciliation as a 'neo-imperial gesture, that amounts, in the Australian context, to a process of re-inscribing a 'post-colonial' political community under one law that 'subordinates indigenous laws and 
customs, once again, in the name of 'civilisation', and its new effigies, democracy and human rights. ${ }^{38}$ Reconciliation as nation building may be viewed as assimilative since it seeks to overcome the state's crisis of legitimacy by incorporating the colonised into the political community as free and equal citizens rather than recognising their right not to reconcile or, in more positive terms, to be self-determining.

The fact that reconciliation was supposed to be achieved to coincide with the centenary of Australian federation in 2001, points to the close connection between the concept of reconciliation and nation building in Australia in the 1990 s. ${ }^{39}$ As Andrew Gunstone discusses, the emphasis placed on improving relations between indigenous and non-indigenous people, on their being united as Australians, living together and sharing histories and cultures, served to marginalise or silence certain indigenous justice claims, such as the right to self-determination, which could not be articulated within the terms of settler nationalism.

This ideological use of the concept was particularly apparent in the fact that while indigenous people had called for a treaty with the Australian state since the 1960s, reconciliation is all they were offered in the 1990s. The reason why reconciliation was more palatable than a treaty to the settler society was clearly elucidated by John Howard while Opposition leader in 1988: 'it is an absurd proposition that a nation should make a treaty with some of its own citizens'. ${ }^{40}$ A treaty suggests retrospective recognition that Aboriginal sovereignty existed at the time of settlement, which would call into question the validity (if not the fact) of the sovereignty of the Australian state now. In contrast, the concept of reconciliation seems to take for granted the sovereignty of the Australian state and co-membership of indigenous and non-indigenous Australians in one nation. More recently, Prime Minister Howard has responded to renewed calls for a treaty at the end of the official reconciliation process by saying that we need to focus on 'what unites us as Australians rather than what divides us. ${ }^{41}$ Of course, even to focus mainly on what "divides us" as Australians would be assimilative to the extent that it presupposes that it is as Australians that "we" are divided.

Yet, while the concept of reconciliation often is employed in this ideological way by nation states, it might potentially be employed to politicise the terms of association in a divided society. 
In particular, the new beginning that reconciliation seeks to enact draws attention to the political risk of (re)founding a political community. For the new beginning that we seek to enact can only be recognised as such in retrospect since it depends on the establishment of a lasting institution. As already discussed, the 'we' that is invoked to found a political community does not exist in the moment in which a new constitution is made, but only comes about to the extent that future generations continue to identify themselves as part of this historical community. If the moral dimension of reconciliation is present in the notion of 'restoring' an original unity, the political dimension is present in this attempt to make a new beginning. The political risk is that the revolutionary act may not succeed. ${ }^{42}$ As Emilios Christodoulidis has observed, this risk that the beginning we seek to enact might fail should be celebrated since, in contrast to the reification of the nation, it imports an awareness that keeps community both attuned to the aspiration of being-in-common and aware of its vulnerability. ${ }^{43}$

It is no coincidence that the revolutions in France and America and more recently in Eastern Europe and South Africa all tend to focus on the establishment of a constitution and the promise 'never again'. Constitution making is historically associated with the attempt to memorialise a new beginning. Indeed, in South Africa, it was only after the establishment of a treaty and a provisional constitution that it was possible to talk of reconciliation. Only with the formal cessation of hostilities is it possible for former enemies to countenance civic friendship and to begin a process of reconciliation.

As such a treaty and reconciliation in Australia are not alternatives. Rather, it is only with the establishment of a treaty (or many treaties) between the settler society and indigenous peoples in Australia that a space for a reconciliatory politics is constituted. A treaty might thus establish the possibility of an inclusion that is not at the same time an incorporation of indigenous people within an Australian nation/state. In the absence of such a treaty, the new beginning that "we" seek to enact in the present is unlikely to be recognised as such by future generations. Indeed, as Rob Sparrow has argued, "we" (members of the settler society at the beginning of the twentyfirst century) are more likely to be perceived by our successors (indigenous and non-indigenous) as one with those 'past generations' from whose actions and attitudes we so readily (and 
anxiously) distance ourselves in the present. ${ }^{44}$ Similarly, in the absence of reconciliation, any treaty that we might make now is unlikely to stand the test of time.

\section{The Quietist Objection}

Reconciliation is often also objected to on the grounds that it places the burden of dealing with a history of political violence on the victims by demanding that they forgive and forget their oppressors when they are entitled to resent and resist them. This objection was strongly put by indigenous writer and activist, Kevin Gilbert when he asked:

What are we to reconcile ourselves to? To a holocaust, to massacre, to the removal of us from our land, from the taking of land? The reconciliation process can achieve nothing because it does not...promise justice. ${ }^{45}$

Invoking the sense of reconciliation as resignation, this objection points to the ideological aspect of reconciliation insofar as it demands letting go of past grievances and, hence, being 'reconciled to domination', ${ }^{46}$

The relation between reconciliation and justice is, indeed, a difficult one. This becomes especially clear when we consider the relation between justice and forgiveness (a concept closely related to reconciliation). Following Aurel Kolnai ${ }^{47}$, the paradox of forgiveness can be stated as follows: on the one hand, forgiveness should be conditional on our wrongdoer repenting, repairing the wrong, reaffirming the norm violated, etc. For if we forgive before this we end up condoning the wrong. On the other hand, if forgiveness is conditional in this way on our wrongdoer deserving to be forgiven, it seems to become redundant. For we seem only to be doing what justice requires. Indeed, to withhold our forgiveness from a person who deserves it would appear unjust or, at least, unvirtuous. ${ }^{48}$

Yet there is also another idea of forgiveness as unconditional, as something that we freely offer to the other, regardless of whether he or she deserves our forgiveness or not, for the sake of establishing or restoring a relationship with her or him. This idea of forgiveness was sometimes referred to in South Africa as a kind of higher morality that transcends the demands

of retributive justice for the sake of restoring community. But to the extent that such 
unconditional forgiveness transcends justice it risks becoming unjust (at least insofar as it is understood on justice's own terms). ${ }^{49}$ Indeed, critics of the Truth and Reconciliation Commission in South Africa argued that Desmond Tutu's insistence on the importance of forgiveness amounted to counselling the oppressed to resign themselves to the injustice of apartheid rather than demanding the distributive and reparative justice they were entitled to.

I agree with Bert van Roermund that political reconciliation requires something a movement back and forth between these two sequences of forgiveness, which he describes in terms of 'rubbing on' and 'rubbing off. ${ }^{50}$ If it is not to amount to a quietist doctrine, then reconciliation should not be understood in opposition to justice. Rather, a willingness to reconcile should be understood as providing a political context in terms of which justice is staged. This requires on the one hand seeking justice through, for instance, reparations, apologies, indigenous rights, constitutional recognition, etc. and at the same time recognising the impossibility of ever being able to fully satisfy the demands of justice. The relation between reconciliation and justice in this way points to the relation between politics and justice in any political society. The ideal of justice depends on political institutions for its (imperfect) realisation and as such, is always worked out within a determinate political community. On the other hand, the possibility of political community depends, in the first place, upon a willingness to forgive on the part of those formerly oppressed. In its ideological aspect reconciliation demands forgiveness from the victims of injustice as a condition of their recognition as free and equal co-members of the political community. As politics, in contrast, reconciliation would be predicated on an awareness of and gratitude that it is only due to a willingness of those formerly oppressed to forgive (in the political sense of being willing to countenance sharing the same political institutions with their former oppressors) that talk of reconciliation is possible at all. Some such awareness did appear to be widespread among whites, for instance, in South Africa in the 1990s where the 'miracle' of the new South Africa was often proclaimed.

\section{The Exculpatory Objection}


Finally, reconciliation, it is sometimes said, enables those ordinary citizens collectively implicated in past injustices as beneficiaries of a regime to evade assuming any real responsibility by lapsing into a sentimental politics of guilt or shame. For instance, symbolic politics such as the signing of sorry books in Australia, emotional outpourings in Parliament, the displays of the 'Sea of Hands' and marches across the Sydney Harbour Bridge only serve to relieve colonial guilt without addressing the very real inequalities that continue to exist, the specific wrongs perpetrated or the particular people unjustly harmed. As Anthony Moran observes in relation to Australia:

A new form of settler nationalism, itself responding to a perception of national illegitimacy, is one of the forces that stimulated the movement for reconciliation. Ideas and feelings about the nation, national belonging, and reconciliation vary, but what 'Aboriginal Reconciliation' means for many of its non-indigenous supporters is the opportunity to free the nation of the guilt or shame associated with its foundations. ${ }^{51}$

In its ideological aspect, reconciliation enables a sentimental avowal of responsibility in order to achieve a sense of belonging to a 'good' nation that is, in fact, an evasion of real liability that would incur material costs in the form of reparations. ${ }^{52}$

While sentimentality can be a way of evading political responsibility, however, we should be careful not to make the opposite mistake of insisting that the grave business of politics requires reasonableness without passion. Politics always begins from outrage at injustice. The sense of shame that many members of the settler society feel for the treatment of indigenous people is Australia, for instance, is an important impulse that can mobilise people to act to change what undoubtedly remains a shameful situation. Yet, this sense of shame becomes sentimental when it centres our attention on how we might feel good about our selves and our nation rather than on what can be done to redress the situation. ${ }^{53}$ Reconciliation is ideological when it becomes exculpatory in this sense.

For a politics of reconciliation, the feeling of shared responsibility needs to be thought of in terms of a responsibility that is responsive to the political claims of those who suffered previous injustice. In the Australian context, such responsiveness would not take for granted the 
membership of indigenous people in the nation nor assume that the interests of the settler society and indigenous people could be reconciled. In recognising the right of indigenous people not to reconcile, such political responsibility would be animated, as Johan van der Walt puts it, by a desire not to be reconciled but to live in reconciliation. ${ }^{54}$

In assuming responsibility in this way, the settler society would not be hoping for forgiveness from indigenous people that would relieve them of their guilt by bringing about a final settlement that would put an end to any future claims for reparative justice. Rather, as Colin Perrin and Scott Veitch suggest, the truth telling and acknowledgement of systematic racial discrimination and genocide reported in Bringing Them Home in Australia, would continue to have an unsettling effect on the political association between settler and indigenous societies. ${ }^{55} \mathrm{~A}$ politics of reconciliation would mean seeking to realise political community while acknowledging a moral debt that cannot be paid, an account that cannot be settled. ${ }^{56}$

\section{Conclusion}

As Paul Ricoeur describes it, the autonomy of the political leads to a paradox in that the rationality of the political (the working out of human coexistence in relation to the good of community) gives rise to the evils of political power (violence against a part of the community legitimised by appeal to the interest of the whole). Against the temptation to oppose two styles of political reflection - on the one side an insistence on 'the rationality of polity' (Hegel) and on the other an insistence on the 'violence and untruth of power' (Marx), the task of political philosophy, according to Ricoeur, is to recognise 'that the greatest evil adheres to the greatest rationality, that there is political alienation because [the political] is relatively autonomous. ${ }^{, 57}$ It is in this spirit that I have undertaken the analysis of the six objections to reconciliation above.

Insofar as it tends to inscribe an enforced commonality, as Stewart Motha puts it (above), reconciliation probably has been ideological in every society in which it has been deployed as state policy. There may be a fundamental change in the membership of the ruling class between the regime that has been overturned and that which a politics of reconciliation would establish. There may be a cessation of overt political violence. As ideology, however, reconciliation would 
nevertheless still be complicit in the exercise of various forms of structural violence in its appeal to an idea of commonality to legitimate a social hierarchy.

As such, reconciliation is a form of what Rancière calls 'the police': 'an order of the visible and the sayable [predicated on a division between rulers and ruled] that sees that a particular activity is visible and another is not, that this speech is understood as discourse and another as noise. ${ }^{58}$ Within the order of the sayable of the ideology of reconciliation, what registers as speech is that which would confirm the unity of the political association. In contrast, any political claim that would question the substantive unity that underlies the political order in the first place could only be perceived as noise. As Rancière observes, the police can 'can procure all sorts of good, and one kind of police may be infinitely preferable to another. ${ }^{59}$ The reconciliatory police order of Chile after the fall of Pinochet is obviously preferable to that of the long years of its authoritarian-capitalist regime.

Yet, as Rancière goes on to say, "Whether the police order is sweet and kind does not make it any less the opposite of politics. ${ }^{60}$ Throughout this article I have therefore sought to recuperate the concept of reconciliation for a politics along something like the lines that Rancière proposes, as a mode of activity that is 'antagonistic to policing'. Politics always calls into question a social order by demonstrating the fundamental equality that it implicitly presupposes. Namely, that both parties to a conflict possess the same faculty of understanding: that to understand a speech as an order, to be able to obey, one must also already possess the capacity for understanding that is denied one by the social order. As such, politics is the staking out of a speaking position that is not made available by a police order: it makes heard as speech what could only register as noise within that order. Politics is predicated on this assumption of equality that 'demonstrates the sheer contingency of the order, the quality of any speaking being with any other speaking being. ${ }^{61}$ Political activity always involves a process of subjectification to the extent that it brings into view this fundamental condition of the police order, the ontological equality that underlies every social hierarchy. As such, politics is the 'practice whereby the logic of the characteristic of equality takes the form of a processing of a wrong., ${ }^{62}$ 
I have sought to develop an account of reconciliation as a processing of a wrong, a demonstration of the fundamental wrong on which the polity is founded which is brought into view by the friction between reconciliation as ideology and politics. Between: over-determination and contestability; privatisation and collectivisation; reifying and invoking unity; certainty and risk; expectation and gratitude; accounting and responsiveness. The significance of the six aspects of reconciliation as politics that I have argued for come down to the possibility of the processing of a wrong or its demonstration, which depends on an awareness of the extent to which the foundation of political community both presupposes a fundamental equality of its members and represses this presupposition in its casting of social conflict as always in the service of a unity. There is both violence in the foundation of every social order (enforced commonality) and the inscription of an ideal equality (on which every emancipatory demand is predicated).

Rancière is an important theorist for us since he attempts to think Ricoeur's political paradox or what Stewart Motha refers to the as the double move of reconciliation. As Rancière acknowledges, politics does not exist in a vacuum: its logic is heterogenous to that of the police but it is always also bound up with it. There is no issue or sphere that is inherently political and politics' guiding principle of equality is not essentially political. What the principle of equality does is 'lend politics reality' in the staging of a conflict that brings into view the fundamental equality underlying every police order. What makes an action political is its form: 'the form in which confirmation of equality is inscribed in the setting up of a dispute, of a community existing solely through being divided ${ }^{63}$ Reconciliation as politics would always concern this setting up of a dispute, the processing of the wrong on which political community is founded.

\footnotetext{
${ }^{1}$ I am grateful to Keith Breen, Emilios Christodoulidis, Claire Moon, Kathy Smits, Ernesto Verdeja and two anonymous reviewers for their helpful comments on an earlier draft of this paper.

${ }^{2}$ See, for instance, Mark Neocleous, 'Let the dead bury their dead: Marxism and the politics of redemption', 128 (2004): 29.

${ }^{3}$ Indeed, I believe this currently to be the case for indigenous people in Australia who remain under siege by the settler society.
} 
${ }^{4}$ Marx \& Engels, 'The German Ideology', excerpted in Karl Marx: Selected Writings, ed. David McLellan (Oxford: Oxford University Press, 1977), p. 176.

${ }^{5}$ Costas Douzinas, The End of Human Rights: Critical Legal Thought at the Turn of the Century (Hart Publishing, Oxford: 2000), p. 169.

${ }^{6}$ Stewart Motha, 'Reconciliation as Domination' in Law and the Politics of Reconciliation, ed. Scott Veitch (Aldershot: Ashgate, 2007), p. 88. John Borneman similarly arrives at a 'Janus-faced' vision of reconciliation. John Borneman, 'Reconciliation after Ethnic Cleansing: Listening, Retribution, Affiliation', Public Culture 14(2) 2002, pp. 301-302.

${ }^{7}$ Andrew Gunstone, 'Unfinished Business: the Australian Reconciliation Process from 1991-2000', Journal of Australian Indigenous Issues 8(4) (2005). Brandon Hamber and Hugo van der Merwe, similarly identify a profusion of meanings of reconciliation in the South African context as a stumbling block toward the possibility of a lasting reconciliation. Brandon Hamber \& Hugo van der Merwe, 'What is this thing called reconciliation?', Reconciliation in Review 1(1) 1998, Centre for the Study of Violence and Reconciliation online paper, http://www.csvr.org.za/articles/artrcbh.htm, last accessed 1 March 2007.

${ }^{8}$ Alternative definitions of the concept include 'an agreement among antagonistic subjects to depart from violence in a shared present' (Borneman) and 'building or rebuilding relationships today that are not haunted by the conflicts and hatreds of yesterday' (Hayner). Borneman, 'Reconciliation after Ethnic Cleansing', p. 300; Priscilla Hayner, Unspeakable Trutbs: Facing the Challenge of Truth Commissions (Routledge, NY \& London, 2002), p. 161.

${ }^{9}$ Michael Freeden explains that, in contrast to being 'essentially contestable' a concept is 'effectively contestable because its contestability is not an essential property of the concept but a property of political discourse', 'Essential contestability and effective contestability', Journal of Political Ideologies 9(1) 2004: 5. ${ }^{10}$ See John Howard, 'Practical Reconciliation' in Reconciliation: Essays on Australian Reconciliation, ed. Michelle Grattan (Melbourne: Bookman Press, 2000), 88-96. It should be noted that this appeal to distributive justice was made in bad faith given the worsening disparity in the distribution of the benefits and burdens of social cooperation between indigenous and non-indigenous people in Australia under the Howard government.

${ }^{11}$ See Paul Keating, 'The Redfern Park speech' in Reconciliation: Essays on Australian Reconciliation, ed. Michelle Grattan (Melbourne: Bookman Press, 2000), 60-64. 
${ }^{12}$ See Geoff Clarke 'Not much progress' in Reconciliation: Essays on Australian Reconciliation, ed. Michelle

Grattan (Melbourne: Bookman Press, 2000), 228-234.

${ }^{13}$ Freeden, 'Essential contestability and effective contestability', 10.

${ }^{14}$ On this point see Emilios Christodoulidis, “"Truth and Reconciliation” as Risks', Social and Legal Studies $9(2)(2000): 179-204$.

${ }^{15}$ Claire Moon, 'Narrating Political Reconciliation: Truth and Reconciliation in South Africa', Social and Legal Studies 15(2) (2006), 272, 260.

${ }^{16}$ For analyses of the debate over an official apology in Australia see Marguerite La Caze, 'The Asymmetry between Apology and Forgiveness', Contemporary Political Theory 5(4) 2006: 447-468; Katherine Smits, 'Deliberating Past Injustices: Apology, Historical Identity and Reconciliation in the Australian Case', Constellations, this issue.

${ }^{17}$ For discussions of the political significance of the theological meanings of reconciliation, critical of this too easy insistence on secularism, see Michael Phillips, 'Aboriginal Reconciliation as Religious Politics,' Australian Journal of Political Science 40(1) (2005): 111-124; Andrew Schaap, 'The proto-politics of reconciliation', Australian Journal of Political Science 41(4) 2006: 615-630; Fernando Atria, 'Reconciliation and Reconstitution' in Law and the Politics of Reconciliation, ed. Scott Veitch, Aldershot: Ashgate, 2007.

${ }^{18}$ Timothy Garton-Ash, 'True Confessions', The New York Review of Books, 17 July 1997, 37.

${ }^{19}$ On reconciliation conceived in terms of democratic reciprocity (conceived in terms of dialogical liberalism as opposed to the liberalism of fear that I discuss here) see Amy Gutmann and Dennis Thompson, 'The moral foundations of truth commission' in Truth v Justice: the morality of truth commissions, ed. Robert I Rotberg \& Dennis Thompson (Princeton: Princeton University Press, 2000). For a critique see my 'Agonism in Divided Societies', Philosophy and Social Criticism 32(2) 2006: 255-277.

${ }^{20}$ Judith Shklar, 'The Liberalism of Fear' in Political Thought and Political Thinkers, ed. Stanley Hoffman (Chicago: University of Chicago Press, 1998), p.11. For recent restatements of this position see Michael Igantieff, Human Rights as Politics and Idolatry, (Princeton: University of Princeton Press, 2001), pp. 55-56; Jonathan 'The Place of Negative Morality in Political Theory', Political Theory 29(3) 2001: 337-363.

${ }^{21}$ For a distinction between thin and thick conceptions of reconciliation see David Crocker 'Truth Commissions, Transitional Justice and Civil Society' in Truth v Justice: the morality of truth commissions, ed. Robert I Rotberg \& Dennis Thompson (Princeton: Princeton University Press, 2000). For a discussion of 
the political implications of these distinctions in the colonial context, see Damien Short, 'Reconciliation and the Problem of Internal Colonialism', Journal of Intercultural Studies 26(3) 2005: 267-282.

${ }^{22}$ Alain Badiou, Ethics: An Essay on the Understanding of Evil, trans. Peter Hallward (London: Verso, 2001), p. 13.

${ }^{23}$ Bert van Roermund, 'Rubbing Off and Rubbing On: the Grammar of Reconciliation' in Lethe's Law: Justice, Law and Ethics in Reconciliation, ed. Emilios Christodoulidis \& Scott Veitch (Oxford: Hart Publishing, 2001), 188. I discuss this issue in my Political Reconciliation (London: Routledge, 2005), ch. 2.

${ }^{24}$ Rancière, Disagreement, 138.

${ }^{25}$ Fernando Atria, 'The Time of Law: Human Rights between Law and Politics', Law and Critique 16 (2005): 137-159.

${ }^{26}$ Atria, 'The Time of Law', p. 138.

${ }^{27}$ Atria, 'The Time of Law', p. 153-154, citing Simone Weil.

${ }^{28}$ Atria, 'The Time of Law', p. 140.

${ }^{29}$ Claire Moon, 'Prelapsarian State: Forgiveness and Reconciliation in Transitional Justice', International Journal for the Semiotics of Law 17 (2004) citing Antjie Krog. See also Neocleous, 'Let the dead bury their dead', p. 29; Rosalyn Diprose, Corporeal Generosity: On Giving with Nietzsche, Merleau-Ponty and Levinas. (Albany: State University of New York Press, 2002), 148.

${ }^{30}$ See, for instance, Christopher Bennett, 'The varieties of retributive experience', The Philosophical Quarterly 52(207) 2002, 145-163.

${ }^{31}$ See Bert van Roermund, 'The concept of representation in parliamentary democracy', Current Legal Theory, 14(1) 1996: 31-52 and 'First-person plural legislature: political reflexivity and representation', Philosophical Explorations, 6(3) 2003: 235-250. The classic expression of the paradox is in Rousseau's Social Contract (2.7.9).

${ }^{32}$ Claude Lefort, Democracy and Political Theory (Cambridge: Polity Press, 1988). 17. As Bernard Flynn explains, in a democracy, 'there is no one who is a priori certified to speak in the name of the people. Each one does speak in the name of the people, but each is legitimately contradicted by others who, with as much right, also evoke the name of the people.' Bernard Flynn, 'Lefort' in S. Critchley \& W Schroeder (eds.) A Companion to Continental Philosophy (Oxford: Blackwell, 1998), 489.

${ }^{33}$ Motha, 'Reconciliation as Domination', p. 77.

${ }^{34}$ Motha, 'Reconciliation as Domination', p. 78 citing the Declaration. 
${ }^{35}$ For reasons powerfully argued by Atria, 'The Time of Law.'

${ }^{36}$ I develop this argument more fully in relation to the work of Lefort in 'The proto-politics of reconciliation'.

${ }^{37}$ Valerie Kerruish, 'Reconciliation, Property and Rights' in Lethe's Law: Justice, Law and Ethics in Reconciliation, ed. Emilios Christodoulidis \& Scott Veitch (Oxford: Hart Publishing, 2001), 200.

${ }^{38}$ Motha, 'Reconciliation as Domination', 77, 69. See also Damien Short, 'Australian 'Aboriginal'

Reconciliation: The Latest Phase in the Colonial Project', Citizenship Studies 7(3) 2003: 291-312.

${ }^{39}$ For the connection between reconciliation and nation building in South Africa see, among others, Richard A Wilson, The Politics of Truth and Reconciliation in South Africa: Legitimizing the Post-Apartheid State (Cambridge: Cambridge University Press, 2001) and Michael Humphrey, The Politics of Atrocity and Reconciliation: From Terror to Trauma (London: Routledge, 2002).

${ }^{40}$ Cited in Paul Patton, 'Reconciliation, Aboriginal Rights and Constitutional Paradox in Australia', The Australian Feminist Law Journal 15(1) (2001), 37.

${ }^{41}$ Howard, 'Practical Reconciliation', 96.

${ }^{42}$ I develop this argument more fully in 'The time of reconciliation and the space of politics' in Law and the Politics of Reconciliation, ed. Scott Veitch (Aldershot: Ashgate, 2007).

${ }^{43}$ Christodoulidis, 'Truth and reconciliation as risks', 198.

${ }^{44}$ Robert Sparrow, 'History and Collective Responsibility', Australasian Journal of Philosophy 78(3) (2003): 346-359.

${ }^{45}$ Cited by Kerruish, 'Reconciliation, Property and Rights', 191.

${ }^{46}$ See also Motha, 'Reconciliation as domination', p. 70.

${ }^{47}$ Aurel Kolnai, 'Forgiveness' in Ethics, Value and Reality (London: The Althone Press, 1977).

${ }^{48}$ Jacques Derrida is probably better known than Kolnai for his thematisation of the aporia between a conditional forgiveness (which he associates with reconciliation) and an pure forgiveness arising from a Levinasian unconditional ethical injunction. See his 'On Forgiveness' in On Cosmopolitanism and Forgiveness (London: Routledge, 2001). For a critical discussion see Ernesto Verdeja, 'Derrida and the impossibility of forgiveness', Contemporary Political Theory 3(1): 23-47.

${ }^{49}$ See Peter Digeser, 'Forgiveness and politics: dirty hands and imperfect procedures', Political Theory 26(5) 1998: 700-724. 
${ }^{50}$ Bert Van Roermund, 'Rubbing Off and Rubbing On: the Grammar of Reconciliation' in Lethe's Law: Justice, Law and Ethics in Reconciliation, ed. Emilios Christodoulidis \& Scott Veitch (Oxford: Hart Publishing, 2001).

${ }^{51}$ Anthony Moran, 'Aboriginal Reconciliation: Transformations in Settler Nationalism', Melbourne Journal of Politics 25 (1998).

${ }^{52}$ See also Anne Orford, 'Commissioning the Truth', Columbia Journal of Gender and Law 15(3) 2006: 877880.

${ }^{53}$ For an Arendtian critique of collective guilt as sentimentality see my 'Guilty Subjects and Political Responsibility', Political Studies 49(4) 2001: 749-7766.

${ }^{54}$ Johan Van der Walt, 'Psyche and Sacrifice: An Essay on the Time and Timing of Reconciliation', Journal of South African Law 4 (2003): 635-651.

${ }^{55}$ Human Rights and Equal Opportunity Commission, Bringing Them Home: National Inquiry into the Separation of Aboriginal and Torres Straight Island Children from their Families, Canberra: AGPS, 1997. For an insightful reading of the report see Anne Orford, 'Commissioning the Truth'.

${ }^{56}$ Colin Perrin \& Scott Veitch 'The Promise of Reconciliation', Law, Text, Culture 4(1)(1998): 225-233.

${ }^{57}$ Paul Ricoeur, 'The Political Paradox' in History and Truth (Evanston: Northwestern University Press, 1965), p. 249.

${ }^{58}$ Jacques Rancière, Disagreement: Politics and Philosophy, trans. Julie Rose (Minneapolis: University of Minnesota Press, 1999), p. 29.

${ }^{59}$ Rancière, Disagreement, p. 31.

${ }^{60}$ Rancière, Disagreement, p. 31.

${ }^{61}$ Rancière, Disagreement, p. 30.

${ }^{62}$ Rancière, Disagreement, p. 35.

${ }^{63}$ Rancière, Disagreement, p. 32. 


\section{University Library}

\section{- M M N E R VA A gateway to Melbourne's research publications}

Minerva Access is the Institutional Repository of The University of Melbourne

Author/s:

Schaap, Dr Andrew W

Title:

Reconciliation as Ideology and Politics

Date:

2007

Citation:

Schaap, Dr Andrew W (2007) Reconciliation as Ideology and Politics.

Persistent Link:

http://hdl.handle.net/11343/34565 